2011-3

\title{
Correlation of p16INK4A Expression and HPV Copy Number with Cellular FTIR Spectroscopic Signatures of Cervical Cancer Cells
}

\author{
Kamila Ostrowska \\ Technological University Dublin \\ Amaya Garcia \\ Technological University Dublin \\ Aidan Meade \\ Technological University Dublin, aidan.meade@tudublin.ie
}

See next page for additional authors

Follow this and additional works at: https://arrow.tudublin.ie/radart

Part of the Medical Cell Biology Commons

\section{Recommended Citation ok6m9e5. doi:10.1039/COAN00910E \\ This Article is brought to you for free and open access by the Radiation and Environmental Science Centre at ARROW@TU Dublin. It has been accepted for inclusion in Articles by an authorized administrator of ARROW@TU Dublin. For more information, please contact arrow.admin@tudublin.ie, aisling.coyne@tudublin.ie, gerard.connolly@tudublin.ie. Funder: HEA TSR Strand III}

Ostrowska, K. et al (2011) Correlation of p16INK4A expression and HPV copy number with cellular FTIR spectroscopic signatures of cervical cancer cells. Analyst, 136, pp.1365-1373. http://tinyurl.com/

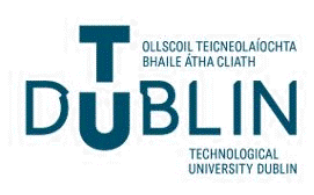




\section{Authors}

Kamila Ostrowska, Amaya Garcia, Aidan Meade, Alison Malkin, Ifeoluwapo Okewumi, John O'Leary, Cara Martin, Hugh Byrne, and Fiona Lyng 


\title{
Correlation of p16 ${ }^{\mathrm{INK4A}}$ expression and HPV copy number with cellular FTIR spectroscopic signatures of cervical cancer cells
}

\author{
Kamila M. Ostrowska, ${ }^{a}$ Amaya Garcia, ${ }^{a}$ Aidan D. Meade, ${ }^{a}$ Alison Malkin, ${ }^{b}$ Ifeoluwapo Okewumi, ${ }^{b}$ \\ John J. O'Leary, ${ }^{c}$ Cara Martin, ${ }^{c}$ Hugh J. Byrne ${ }^{d}$ and Fiona M. Lyng ${ }^{a}$
}

\author{
Received (in $X X X, X X X)$ Xth $X X X X X X X X X 200 X$, Accepted Xth XXXXXXXXX 200X \\ First published on the web Xth $X X X X X X X X X 200 X$ \\ DOI: 10.1039/b000000x
}

Cervical cancer, a potentially preventable disease, has its main aetiology in infection by high risk 10 human papillomavirus (HR-HPV). Approaches to improving cervical cancer screening and diagnostic methodologies include molecular biological analysis, targeting of biomarker proteins, but also exploration and implementation of new techniques such as vibrational spectroscopy. This study correlates the biomarker protein $\mathrm{p} 16^{\mathrm{INK} 4 \mathrm{~A}}$ expression levels dependent on HPV copy number with the infrared absorption spectral signatures of the cervical cancer cell lines, HPV negative

${ }_{15} \mathrm{C} 33 \mathrm{~A}, \mathrm{HPV}-16$ positive SiHa and CaSki and HPV-18 positive HeLa. Confocal fluorescence microscopy demonstrated that $\mathrm{p} 16^{\mathrm{INK} 4 \mathrm{~A}}$ is expressed in all investigated cell lines in both nuclear and cytoplasmic regions, although predominantly in the cytoplasm. Flow cytometry was used to quantify the $16^{\mathrm{INK} 4 \mathrm{~A}}$ expression levels and demonstrated a correlation, albeit nonlinear, between the reported number of integrated HPV copies and $\mathrm{p} 16^{\mathrm{INK} 4 \mathrm{~A}}$ expression levels. CaSki cells were

20 found to have the highest level of expression, HeLa intermediate levels, and SiHa and C33A the lowest levels. FTIR spectra revealed differences in nucleic acid, lipid and protein signatures between the cell lines with varying HPV copy number. Peak intensities exhibited increasing tendency in nucleic acid levels and decreasing tendency in lipid levels with increasing HPV copy number, and although they were found to be nonlinearly correlated with the HPV copy number,

25 their dependence on $\mathrm{p} 16^{\mathrm{INK} 4 \mathrm{~A}}$ levels was found to be close to linear. Principal Component Analysis (PCA) of the Infrared absorption spectra revealed differences between nuclear and cytoplasmic spectroscopic signatures for all cell lines, and furthermore clearly differentiated the groups of spectra representing each cell line. Finally, Partial Least Squares (PLS) analysis was employed to construct a model which can predict the $\mathrm{p} 16^{\mathrm{INK} 4 \mathrm{~A}}$ expression level based on a spectral fingerprint 30 of a cell line, demonstrating the diagnostic potential of spectroscopic techniques.

\section{Introduction}

Cervical cancer is a potentially preventable disease and it remains the second most common malignancy in women worldwide ${ }^{1}$. The incidence rates range from less than 15 per 35100,000 in Europe up to 33.5 per 100,000 in Latin America ${ }^{2}$. Many aetiological factors are associated with cervical cancer, such as diet, cigarette smoking, multiple sexual partners, multiple pregnancies, contraceptive pills, sexually transmitted diseases (Chlamydia, HIV) or aging. However, the most 40 important factor identified is infection with high risk human papillomavirus (HR-HPV) ${ }^{3}$. There are 15 identified HR-HPV types ${ }^{4}$ and $70 \%$ of all cervical cancers are associated with either HPV-16 or HPV-18.

Differentially expressed proteins in cancer have potential 45 utility as biomarkers. As the cell cycle is often disrupted in a cancerous cell, proteins associated with it are often candidate biomarkers. Putative biomarkers of cervical cancer that are currently under study include proteins such as CDC 6 (DNA licensing protein), minichromosome maintenance proteins 50 (MCM 2, MCM 5), p53 or p16 $6^{\text {INK4A } 5}$. These biomarkers have been used to detect the presence of abnormal cells, based upon immunocytochemical methods.

p $16^{\text {INK4A }}$ regulates the levels of active cyclin D/CDK in the cell, providing a feedback mechanism that regulates the levels 55 of MCM (minichromosome maintenance proteins), PCNA (proliferating-cell nuclear antigen) and cyclin E. Overexpression of $\mathrm{p} 16^{\mathrm{INK} 4 \mathrm{~A}}$, which is considered a marker of elevated E7 expression, can be detected in some CIN1 (Cervical Intraepithelial Neoplasia grade 1) lesions, as well as ${ }_{60}$ in CIN2 and CIN3 lesions that show evidence of integration ${ }^{6-}$ 7. Integration of the HPV genome into the host cell chromosome is a critical event in the development of most cervical cancers ${ }^{8}$. Overexpression of $\mathrm{p} 16^{\mathrm{INK} 4 \mathrm{~A}}$ has been demonstrated in cervical cancers as a result of functional ${ }_{65}$ inactivation of $\mathrm{pRb}$ by the HPV E7 protein ${ }^{9}$. This overexpression highlights the potential of $\mathrm{p} 16^{\mathrm{INK} 4 \mathrm{~A}}$ as a marker for CIN and cervical cancer. HPV positivity and p16 ${ }^{\text {INK4A }}$ positivity have shown a correlation, even though p16 ${ }^{\mathrm{INK} 4 \mathrm{~A}}$ expression was also seen in a limited number of 70 HPV negative biopsy samples ${ }^{10}$. Also, a correlation between p $16^{\text {INK4A }}$ expression and cervical lesion grade and HR-HPV positivity has been documented ${ }^{11} \cdot \mathrm{p} 16^{\mathrm{INK} 4 \mathrm{~A}}$ has been proven to be the most reliable marker of cervical dysplasia and was 
found to mark all grades of squamous and glandular lesions of the cervix. The use of $\mathrm{p} 16^{\mathrm{INK} 4 \mathrm{~A}}$ immunocytochemical analysis as a complement to conventional screening programmes could potentially aid in the reduction of false positive and false 5 negative results ${ }^{12}$.

In the first part of this study, expression of $\mathrm{p} 16^{\mathrm{INK} 4 \mathrm{~A}}$ was analysed in cervical cancer cell lines using immunocytochemical staining and both confocal fluorescence microscopy and flow cytometry. Confocal fluorescence 10 microscopy is an optical imaging technique that allows for high-resolution structural imaging at the cellular level at varying depths in the sample while flow cytometry is a well established technique for examining and sorting fluorochrome-labeled cells, simultaneously providing 15 assessment of a multitude of characteristics of individual cells.

Four cervical cell lines were used in this study: HPV negative C33A, HPV-18 positive HeLa containing 20-50 integrated HPV copies per cell, HPV-16 positive CaSki containing 60${ }_{20} 600$ integrated HPV copies per cell and $\mathrm{SiHa}$ with 1-2 integrated HPV-16 copies per cell.

The second part of the study utilised Fourier Transformed Infrared (FTIR) Spectroscopy to spectroscopically fingerprint and differentiate the cervical cancer cell lines. FTIR, along 25 with Raman spectroscopy, is a vibrational spectroscopic technique which provides unique information about the chemical composition of a sample. A wide range of biological applications, particularly cancer detection, has been reported to date ${ }^{13-19}$. The development of applications of vibrational 30 spectroscopy to medical diagnostics has recently been reviewed by Diem et al. ${ }^{20}$. Significant activity in the area of the potential application of FTIR spectroscopy to cervical cancer detection has been reported over the last decade ${ }^{17,21-}$

43. Understanding and processing the biochemical information 35 delivered by vibrational spectroscopic techniques and its correlation with the existing screening and diagnostic methods is key to further development of realistic applications of Raman and FTIR spectroscopy to cervical cancer detection.

It has recently been demonstrated that both Raman and FTIR 40 absorption spectroscopy can effectively discriminate between cell lines with varying HPV infection levels ${ }^{44}$. The current study explores the potential correlation of spectroscopic features with HPV infection levels characteristic of each cell line as well as the resultant expression levels of $\mathrm{p}^{16 \mathrm{INK} 4}$ 45 biomarker.

\section{Materials and Methods}

\section{Cell culture and immunocytochemistry}

Cell lines were obtained from the ATCC cell culture collection. All cell lines were grown in RPMI 1640 medium 50 (Sigma-Aldrich, Ireland) supplemented with $10 \%$ Foetal Bovine Serum (FBS, BioWhittaker ${ }^{\circledR}$, Lonza, Ireland), 1\% Penicillin-Streptomycin (BioWhittaker®, Lonza, Ireland), 1\% L-glutamine (Sigma-Aldrich, Ireland), and $0.2 \%$ Hydrocortisone (Sigma-Aldrich, Ireland). Cells were 55 incubated at $37^{\circ} \mathrm{C}$ in $5 \% \mathrm{CO} 2$ and maintained up to $70-80 \%$ confluency.
Immunocytochemical staining for $\mathrm{p} 16^{\mathrm{INK} 4 \mathrm{~A}}$ was performed on each of the cell lines and appropriate negative controls. Cells were fixed using $4 \%$ paraformaldehyde for $30 \mathrm{mins}$, washed 3 60 times with phosphate buffered saline (PBS) and permeabilised with cold methanol for 10mins. Cells were blocked by incubating with blocking buffer (1\% bovine serum albumin (BSA) in PBS) for 30mins at room temperature with agitation. After decanting the serum, cells were incubated for one hour 65 at $37^{\circ} \mathrm{C}$ with the primary antibody, purified mouse anti-human p16 ${ }^{\mathrm{INK} 4 \mathrm{~A}}$ (BD Pharmingen ${ }^{\mathrm{TM}}$, Ireland) in dilution buffer $(1 \%$ BSA in PBS). Following incubation, cells were washed 5 times with PBS and were incubated with the secondary antibody, goat polyclonal to mouse Immunoglobulin G (IgG) 70 (Abcam, Ireland) labeled with fluorescein isothyocyanate (FITC) in dilution buffer. This was carried out in darkness for $45 \mathrm{mins}$ at $37^{\circ} \mathrm{C}$. The cells were additionally incubated with propidium iodide (PI) staining solution (dilution 1:250) (BD Pharmingen ${ }^{\mathrm{TM}}$, Ireland) for $15 \mathrm{mins}$ and washed 3 times with 75 PBS. A negative control was also prepared for each cultured cell line according the same protocol but with no primary antibody (NC1) and no primary or secondary antibody (NC2).

\section{Sample preparation}

\section{Confocal microscopy}

${ }_{80}$ For confocal microscopy, cells were grown on glass coverslips in 6 well plates and stained as described above. Each coverslip with the stained cells was removed from the multi well plate and mounted upside down on a pre-labelled glass slide using Sigma diagnostic mounting medium (Sigma85 Aldrich, Ireland). Samples were left to dry in a dark room and thereafter stored at $4^{\circ} \mathrm{C}$ until they were examined under the confocal microscope.

\section{Flow cytometry}

Flow cytometry samples were stained as a pellet in Eppendorf 90 tubes according to the staining protocol described above. Pellets were examined directly after the staining procedure.

\section{FTIR spectroscopy}

Cervical cell lines for FTIR study were grown for 24 hours on $\mathrm{CaF}_{2}$ windows. Cells prepared for FTIR study were not fixed 95 to avoid contibution of the fixative agent to the cellular spectra ${ }^{45}$. Before FTIR measurements, cells were washed twice in PBS and dried to minimise contributions from water.

\section{Measurements and data handling}

Confocal fluorescence microscopy

100 An inverted confocal laser scanning fluorescence microscope (LSM 510 META, Carl Zeiss) was used to record fluorescence images of the cells. The argon ion laser was chosen to excite the FITC fluorochromes at $488 \mathrm{~nm}$ and the HeNe laser was used to excite the PI fluorochromes at 543nm. A $63 \times$ oil 105 immersion objective lens was used for recording. Five to six images were collected for each sample from different regions of the slides.

\section{Flow cytometry}

A CyFlow ${ }^{\circledR}$ Space Flow cytometer System (Partec) was used 110 for the cervical cell analysis. Measurements were performed for each cell line, represented by 2-4 samples, prepared as stained cellular pellets. Fluorescence intensity of the staining was calculated based on analysis of approx $2 \times 10^{4}$ cells for 


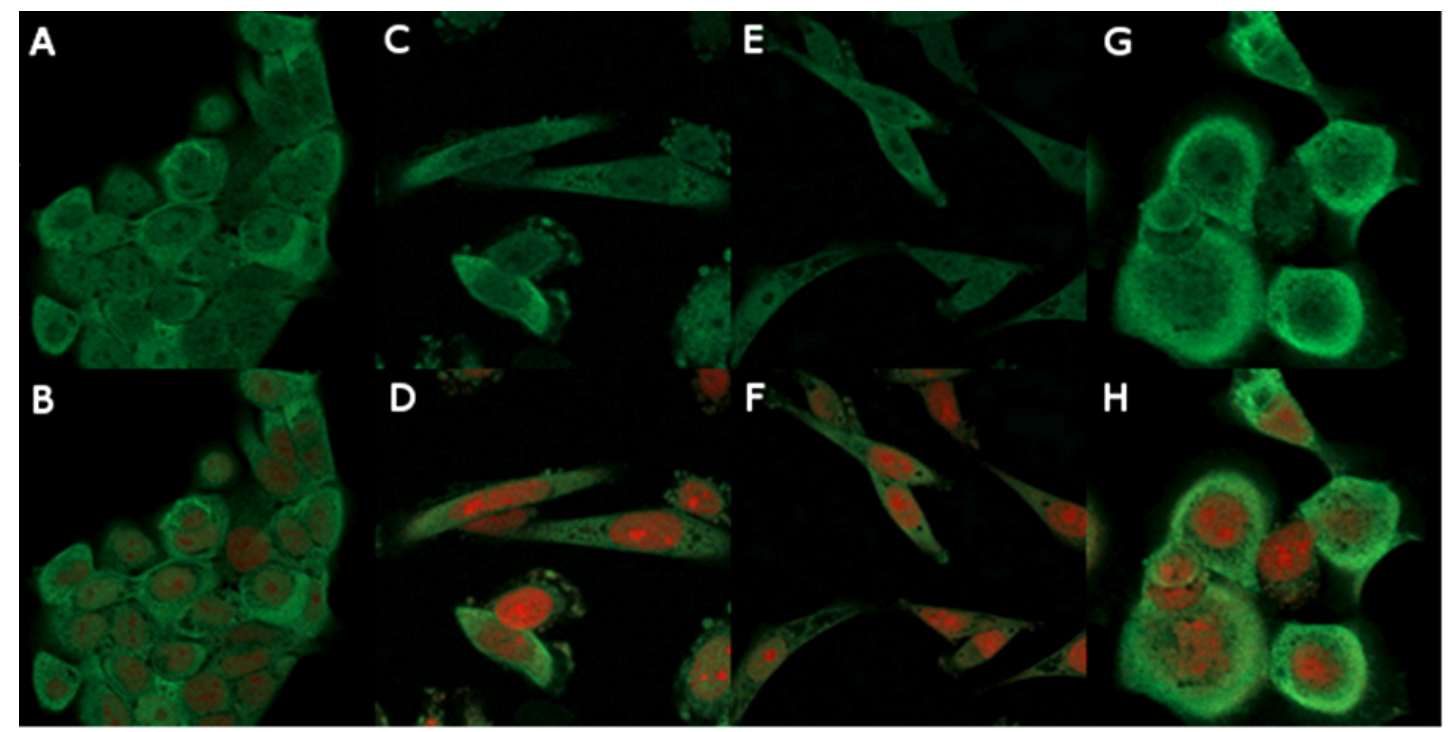

Fig. 1 Confocal microscopy images of cervical cell lines: A-B C33A cells, C-D SiHa cells, E-F HeLa cells, G-H CaSki cells. Images A,C, E and G show FITC fluorescence staining (related to $\mathrm{p} 16^{\mathrm{INK} 4 \mathrm{~A}}$ expression), while images B, D, F and $\mathrm{H}$ present FITC and PI staining.

each sample. Analysis of the data set was performed using ${ }_{5}$ FloMax 3.0 software. Gating R1 selected a well defined population of cells excluding any possible debris present in the samples. Gating R2 was performed to exclude doublets and triplets of cells analysed by the instrument. The subsequent step included applying gating G1 (logical gate of

${ }_{10} \mathrm{R} 1$ and R2) to the investigated fluorescence signal and choosing the range of interest within which fluorescence intensity calculations were performed.

\section{Infrared spectroscopy}

Fourier Transformed Infrared (FTIR) spectroscopic 15 measurements were performed using a Perkin Elmer Spotlight 400 microscope system in transmission mode. The time frame between washing the FTIR samples with PBS and start of acquiring spectra was 30-40minutes. Spectra were collected as an average of 64 scans with a resolution of $2 \mathrm{~cm}^{-1}$ using Image 20 Mode. FTIR signals were accumulated over a spectral range of 750 to $4000 \mathrm{~cm}^{-1}$. Signals were accumulated with the maximal imaging resolution of the system of $6.25 \mu \mathrm{m}$ per pixel. The sampling included investigation of two cell culture passages prepared on separate slides. Four to five cells per 25 slide were analysed.

Spectroscopic data analysis was carried out in Matlab, version R2006 (Mathworks, CA, USA) according to protocols developed and routinely used in DIT. Processing of the FTIR spectra included an EMSC resonant Mie scattering correction 30 according to the algorithm developed by Bassan et al. ${ }^{46}$ with the Matrigel spectrum supplied with the algorithm used as reference. In the original work, it was demonstrated using simulated spectra that the algorithm, which iteratively evolves the reference spectrum to fit and correct for both the resonant 35 and nonresonant scattering contributions, reproduces the ideal spectra even using a "non-ideal" reference and that for example the true position of the biologically significant Amide I band can be obtained with the RMieS-EMSC algorithm ${ }^{46}$. After pre-processing the spectra, Principal ${ }_{40}$ Component Analysis (PCA) and Partial Least Squares (PLS) analysis were performed on the data set. It should be noted that, although the spectra were recorded over the range 750 $4000 \mathrm{~cm}^{-1}$, the Mie scattering correction was only executable over the maximum range of the reference spectrum provided 45 with the algorithm, namely $1000-4000 \mathrm{~cm}^{-1}$, and thus only this region is described.

\section{Results and Discussion}

\section{Confocal microscopy}

Fluorescence images of cells were collected using the 50 confocal fluorescence microscopy system. Representative images of cells are presented in figure 1, where A, C, E and G show only green fluorescence staining (FITC), while B, D, F and $\mathrm{H}$ show the overlay of green (FITC) and red (PI) fluorescence signals. The FITC fluorescence intensity is 55 associated with the $\mathrm{p} 16^{\mathrm{INK} 4 \mathrm{~A}}$ expression level, while the PI dye was used to visualise the position of nuclei within the cells. The fluorescence intensities for the defined FITC fluorescence emission wavelengths for the samples stained with primary and secondary antibody (p16 $6^{\mathrm{INK} 4 \mathrm{~A}}$ staining) and ${ }_{60} \mathrm{NC} 1$ and NC2 samples were compared. The results revealed a strong emission peak for samples stained with primary and secondary antibody and negligible emission for the negative control samples (NC1 and NC2) (data not shown). Based on these observations, immunostaining was found to be specific 65 to $\mathrm{p} 16^{\mathrm{INK} 4 \mathrm{~A}}$. Figure 1 shows that purified mouse monoclonal anti-human $\mathrm{p} 16^{\mathrm{INK} 4 \mathrm{~A}}$ stains both cytoplasmic and nuclear regions of the cells, although staining is predominantly in the cytoplasm. The presence of $\mathrm{p} 16^{\mathrm{INK} 4 \mathrm{~A}}$ in the cytoplasmic region may be a result of post transcriptional modification or 70 overexpression of the protein, which forces its transfer into the cytoplasm ${ }^{12}$. These findings support previous studies confirming the theory that $\mathrm{p} 16^{\mathrm{INK} 4 \mathrm{~A}}$ is overexpressed in dysplastic cells of the cervix ${ }^{47}$. The observations are in very good agreement with the work of Klaes et al., who ${ }_{75}$ demonstrated that the $\mathrm{p} 16^{\mathrm{INK} 4 \mathrm{~A}}$ specific immunohistochemical 
Table 1 Quantitative analysis of fluorescence intensity related to $\mathrm{p} 16^{\mathrm{INK} 4 \mathrm{~A}}$ expression level and negative control samples with no secondary antibody for cervical cancer cell lines obtained from flow cytometry studies.

\begin{tabular}{|c|c|c|c|c|c|}
\hline \multirow[b]{2}{*}{ Cell line } & \multirow[b]{2}{*}{$\begin{array}{l}\text { Reported number } \\
\text { of HPV copies } \\
\text { per cell }\end{array}$} & \multicolumn{2}{|c|}{ p16 ${ }^{I N K 4 A}$ expression } & \multicolumn{2}{|c|}{ Negative controls (NC1) } \\
\hline & & $\begin{array}{l}\text { Fluorescence } \\
\text { intensity } \\
\text { (a.u.) }\end{array}$ & $\begin{array}{l}\text { Standard deviation } \\
\text { for fluorescence intensity } \\
\text { (a.u.) }\end{array}$ & $\begin{array}{l}\text { Fluorescence } \\
\text { intensity } \\
\text { (a.u.) }\end{array}$ & $\begin{array}{c}\text { Standard deviation } \\
\text { for fluorescence intensity } \\
\text { (a.u.) }\end{array}$ \\
\hline C33A & 0 & 61.92 & 1.42 & 1.32 & 0.06 \\
\hline $\mathrm{SiHa}$ & $1-2$ & 68.14 & 1.23 & 1.18 & 0.08 \\
\hline HeLa & $20-50$ & 80.10 & 1.92 & 1.17 & 0.01 \\
\hline CaSki & $60-600$ & 94.31 & 1.77 & 1.41 & 0.11 \\
\hline
\end{tabular}

staining allows for sensitive and specific identification of 5 dysplastic cervical cells in cervical cancer tissue sections and cervical cancer cell lines ${ }^{48}$. The results also support the findings of Murphy et al., that $\mathrm{p} 16^{\mathrm{INK} 4 \mathrm{~A}}$ marks dysplastic squamous and glandular cells of the cervix with a sensitivity of $99.9 \%$ and specificity of $100 \%{ }^{49}$. The negative HPV cell 10 line C33A was $\mathrm{p} 16^{\mathrm{INK} 4 \mathrm{~A}}$ positive (figure $1 \mathrm{~A}-\mathrm{B}$ ), but exhibited the lowest staining intensity of the investigated cell lines. This finding confirms the previous study of Milde-Langosch et al. in which $\mathrm{p} 16^{\mathrm{INK} 4 \mathrm{~A}}$ overexpression was reported in $41 \%$ of HPV negative adenocarcinomas and it was suggested that a 15 non-HPV E7 mediated mechanism of $\mathrm{p} 16^{\mathrm{INK} 4 \mathrm{~A}}$ up regulation may also exist ${ }^{50}$.

Quantitative analysis of the fluorescence intensity of FITC visible in the confocal images, albeit on a limited number of individual cells, indicated that there is a correlation between 20 the number of integrated HPV copies per cell and $\mathrm{p} 16^{\mathrm{INK} 4 \mathrm{~A}}$ expression characteristic to each cell line. CaSki cells were found to have the highest intensity of staining, with decreasing tendency for HeLa and $\mathrm{SiHa}$ and C33A expressing the lowest intensity (data not shown).

\section{${ }_{25}$ Flow cytometry}

To more precisely quantify expression of $\mathrm{p} 16^{\mathrm{INK} 4 \mathrm{~A}}$ protein in cervical cancer cell lines, flow cytometry measurements were performed to enable a larger statistical basis. For all the investigated cell lines, the populations were well defined, 30 allowing for a precise investigation of the cells of interest.

Mean fluorescence intensity levels related to $\mathrm{p} 16^{\mathrm{INK} 4 \mathrm{~A}}$ expression are presented in table 1 together with their standard deviations. Values of fluorescence intensity for negative control (NC1) samples prepared for the investigated 35 cell lines according to the immunostaining protocol but with no primary antibody are also presented in table 1 . Values of fluorescence intensities for NC1 were lower than the standard deviations for fluorescence intensities related to $\mathrm{p} 16^{\mathrm{INK} 4 \mathrm{~A}}$ expression, confirming that the flow cytometry analysis was 40 specific to $\mathrm{p} 16^{\mathrm{INK} 4 \mathrm{~A}}$. A degree of correlation between the number of HPV copies per cell line and the fluorescence intensity related to $\mathrm{p} 16^{\mathrm{INK} 4 \mathrm{~A}}$ expression was observed for the flow cytometry data (figure 2 ). The highest level of $\mathrm{p} 16^{\mathrm{INK} 4 \mathrm{~A}}$ expression (intensity of staining) was observed for CaSki 45 cells, followed by HeLa, SiHa and the lowest for C33A. The relationship between $\mathrm{p} 16^{\mathrm{INK} 4 \mathrm{~A}}$ expression and HPV copy number illustrated by figure 2 is supported by a study

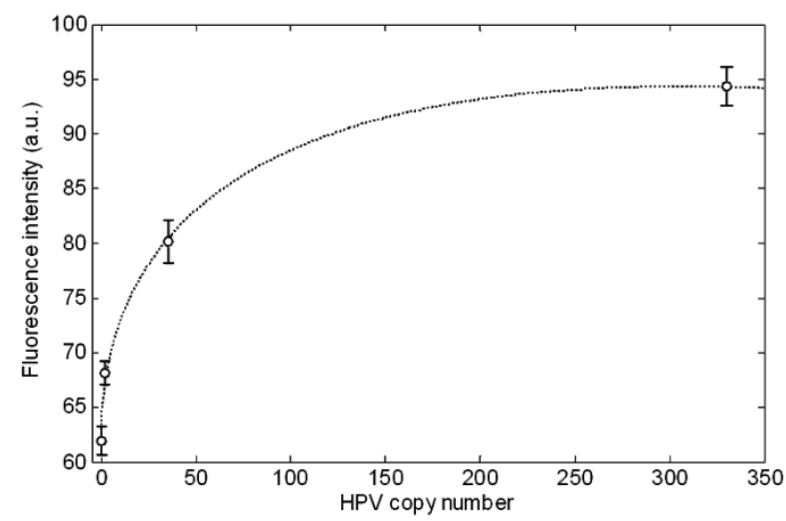

Fig. 2 Fluorescence intensity related to the $\mathrm{p} 16^{\mathrm{INK} 4 \mathrm{~A}}$ expression level in 50 cervical cancer cell lines plotted against the average HPV copy number present in a cell with the fitted function. The dotted line is a fit of the data

with the equation $y=a+b \sqrt{x}+c x$, where $\mathrm{a}=62.4, \mathrm{~b}=3.5$ and $\mathrm{c}=-0.1$.

conducted by Klaes et al., wherein a correlation between increasing grade of cervical lesion and staining intensity of ${ }_{55} \mathrm{p} 16^{\mathrm{INK} 4 \mathrm{~A}}$ was observed ${ }^{48}$. Similarly, Agoff et al. showed that p16 ${ }^{\text {INK4A }}$ expression correlates with an increasing severity of cervical disease ${ }^{51}$. Murphy et al. showed a strong correlation between HR-HPV positivity and $\mathrm{p} 16^{\mathrm{INK} 4 \mathrm{~A}}$ staining pattern ${ }^{12}$, 52-53. In the study conducted by Wang et al. a correlation ${ }_{60}$ between $\mathrm{p} 16^{\mathrm{INK} 4 \mathrm{~A}}$ immunostaining and cervical disease severity stratified by HPV status was observed ${ }^{54}$. The results in the present study demonstrate a correlation between

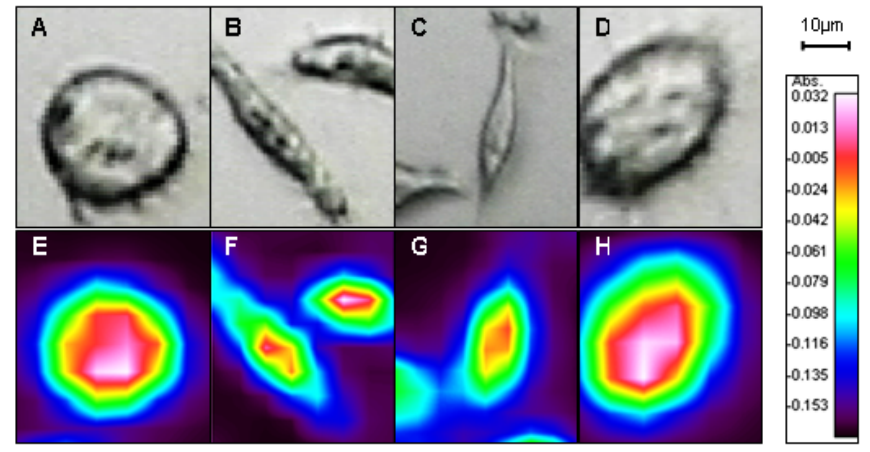

Fig. 3Visual images (A-D) and average absorbance FTIR maps (E-H) 65 representing cells present in the investigated samples. A and E-C33A cell, B and F - SiHa cells, C and G- HeLa cells, D and H - CaSki cells. Red colour represents region of a nucleus, green and light blue - region of a cytoplasm, violet - background. 
Table 2. Assignments ${ }^{55}$ of FTIR bands of cellular spectra recorded from cervical cancer cells. Wavenumbers in brackets are attributed to peaks characteristic of cytoplasmic spectra that were noticed to be shifted with respect to peaks corresponding to nuclear constituents.

\begin{tabular}{|c|c|c|c|c|c|}
\hline Peak no. & $\begin{array}{c}\text { Wavenumber } \\
\qquad\left(\mathrm{cm}^{-1}\right)\end{array}$ & Assignment & Proteins & Lipids & Nucleic acids \\
\hline I & 1036 & C-C skeletal stretching & + & & \\
\hline II & $1070(1082)$ & symmetric $\mathrm{PO}_{2}$ str. mode & & & DNA, RNA \\
\hline III & 1120 & C-O stretching & & & RNA \\
\hline IV & 1170 & CO-OC asymmetric stretching & + & & \\
\hline $\mathrm{V}$ & 1240 & Amide III, asymmetric $\mathrm{PO}_{2}$ str. mode & + & & DNA, RNA \\
\hline VI & $1310(1316)$ & $\mathrm{CH}_{2}$ stretching & & + & \\
\hline VII & 1400 & $\mathrm{CH}_{3}$ symmetric deformations & + & & \\
\hline VIII & 1450 & $\mathrm{CH}_{3}$ asymmetric deformations & + & + & \\
\hline IX & 1550 & $\mathrm{C}-\mathrm{N}$ stretching and $\mathrm{CHN}$ bending -Amide II & + & & \\
\hline $\mathrm{X}$ & 1650 & $\mathrm{C}=\mathrm{O}$ stretching - Amide I & + & & \\
\hline XI & 2854 & $\mathrm{CH}_{2}$ symmetric stretching & & + & \\
\hline XII & 2875 & $\mathrm{CH}_{3}$ symmetric stretching & & + & \\
\hline XIII & 2926 & $\mathrm{CH}_{2}$ asymmetric stretching & & + & \\
\hline XIV & 2962 & $\mathrm{CH}_{3}$ asymmetric stretching & & + & \\
\hline $\mathrm{XV}$ & $3292(3300)$ & N-H stretching (Amide A) & + & & DNA, RNA \\
\hline
\end{tabular}

p16 ${ }^{\mathrm{INK} 4 \mathrm{~A}}$ immunostaining and the presence of HR-HPV in 5 cervical cancer cell lines supporting the previous studies and implies that $\mathrm{p} 16^{\mathrm{INK} 4 \mathrm{~A}}$ is a highly sensitive marker of HR-HPV in cervical cancer cell lines. The hyperbolic-like relationship between the levels of $\mathrm{p} 16^{\mathrm{INK} 4 \mathrm{~A}}$ and HPV copy number is typical of the response of a cell to the action of an agonist ${ }^{56}$ and in figure 102 , is approximated by a fit with the following function $y=a+b \sqrt{x}$ $+c x$, where $\mathrm{a}=62.4, \mathrm{~b}=3.5$ and $\mathrm{c}=-0.1$. It should be noted that, in figure 2, the HPV copy number is represented by the average of the range quoted in literature ${ }^{57-58}$ and so error margins in the horizontal axis are potentially very large. However, the sublinear 15 nature of the plot indicates that $\mathrm{p} 16^{\mathrm{INK} 4 \mathrm{~A}}$ expression levels are particularly sensitive for low HPV copy number.

\section{FTIR spectroscopy}

FTIR maps were recorded for C33A, SiHa, HeLa and CaSki cells (2-4 maps for each cell line) using the Perkin Elmer ${ }_{20}$ Spotlight 400 system. Representative images are presented in figure 3 (A-D). Representative unprocessed FTIR maps, generated by the Spectrum Image software, showing spectrally averaged absorbances, recorded from the regions of interest within the investigated samples are shown in figure 3,

${ }_{25} \mathrm{E}, \mathrm{F}, \mathrm{G}$ and H, for C33A, SiHa, HeLa and CaSki, respectively. Nuclear and cytoplasmic regions are well defined, due to their varying density and thickness, in the FTIR maps. Spectra representing nuclear and cytoplasmic regions of the cells were extracted from the FTIR maps using the Perkin Elmer 30 Spectrum IMAGE software and delivered mean spectra of cellular structures characteristic of the cell lines (figure 4). Spectra extracted from the maps were chosen from the middle of the nucleus or cytoplasm. As a result, from 60-80 spectra recorded for one cell, only a few of them were used in the 35 analysis. This procedure ensured that only nuclear or cytoplasmic signals were compared rather than a mix of the cellular signatures. Each spectrum from figure 4 was

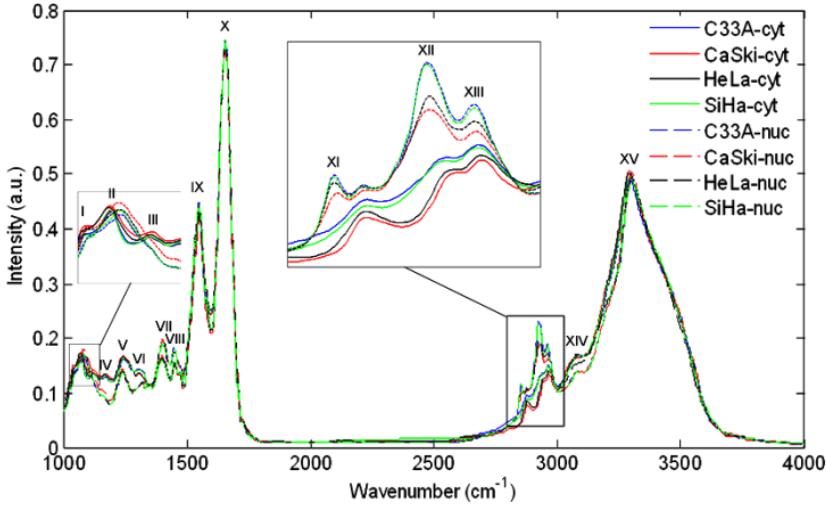

Fig. 4 Mean FTIR spectra of cervical cancer cell lines representing regions of cells (nucleus and cytoplasm).

calculated as an average of 30-40 signals extracted from the FTIR maps characteristic of the defined cellular structure and was subjected to pre-processing using the RMieS-EMSC algorithm. Assignments of the main FTIR bands (numbered in 45 figure 4) are presented in table 2. Three main biochemical cellular components feature strongly: proteins, lipids and nucleic acids. For all cell lines, the nuclear and cytoplasmic regions exhibited similar FTIR bands related to the vibrations of these constituent components. There were, however, 50 differences in the band intensities. A distinctive reduction of lipids was noticed in the IR signal of the cytoplasm compared to the signal of the nucleus, manifest in the $\mathrm{CH}_{2}$ and $\mathrm{CH}_{3}$ groups stretching bands in the range of $2850 \mathrm{~cm}^{-1}-2970 \mathrm{~cm}^{-1}$, due to the double lipid bilayer nuclear envelope, compared to 55 the phospholipid bilayer membrane of the cytoplasm. Furthermore, the peak at $1120 \mathrm{~cm}^{-1}$ is present only in the cytoplasm. This feature is related to vibrations of RNA components, which are mainly present in the cytoplasmic organelles. Three peaks related to cytoplasmic constituent 

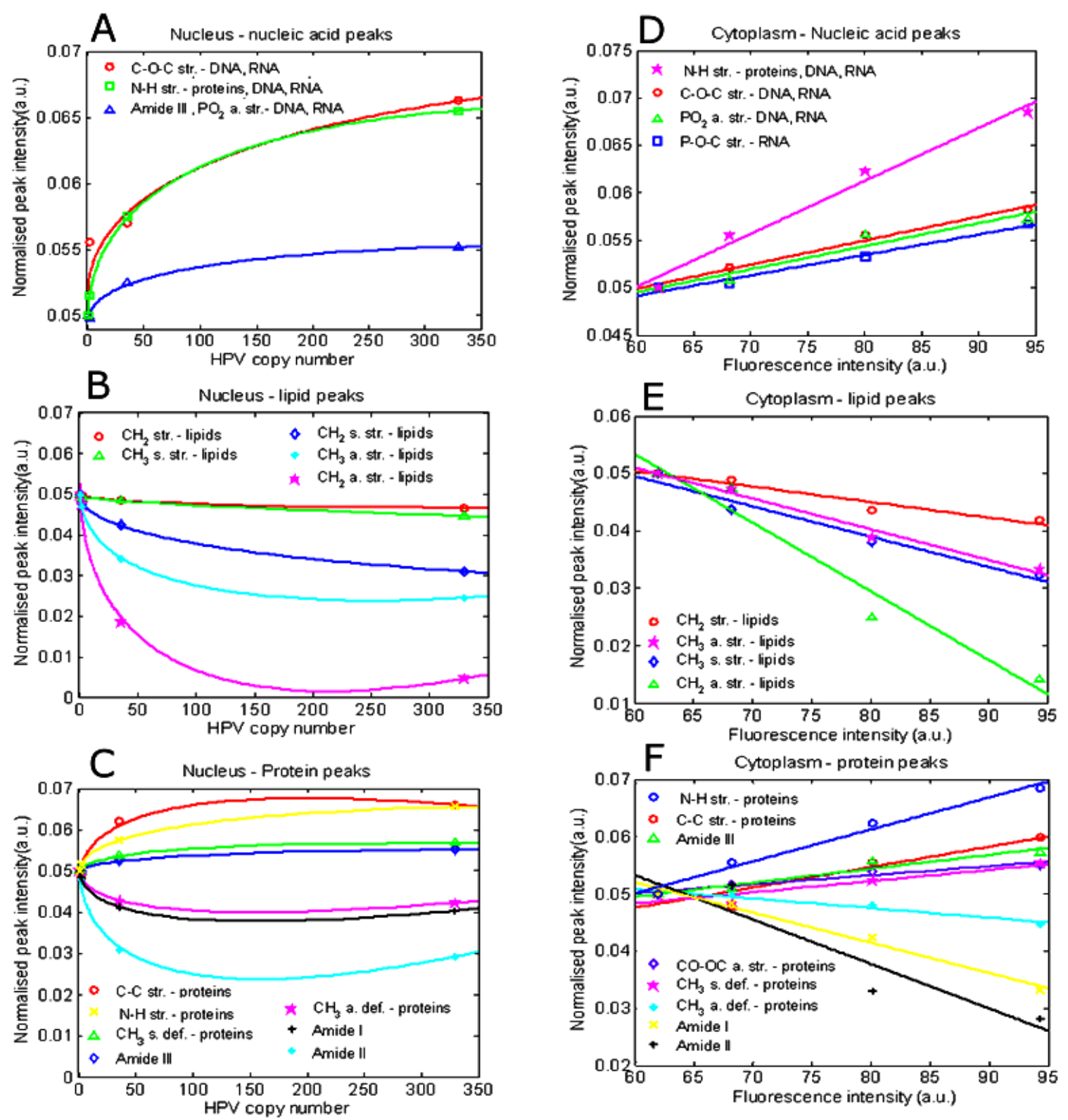

Fig. 5 Peak intensity analysis for FTIR spectra of nuclear and cytoplasmic regions of cervical cancer cells. Dependence of peak intensities vs. HPV copy number was fit with $y=a+b \sqrt{ } x+c x$ function, while peak intensities vs. fluorescence intensities (p16 ${ }^{\mathrm{INK} 4 \mathrm{~A}}$ expression level) was fit with a linear function, $y=a+b x$.

5 vibrations were also noticed to be shifted to higher wavenumbers $\left(1082 \mathrm{~cm}^{-1}, 1316 \mathrm{~cm}^{-1}, 3300 \mathrm{~cm}^{-1}\right)$ compared to nuclear bands related to the same types of vibration $\left(1070 \mathrm{~cm}^{-}\right.$ $\left.{ }^{1}, 1310 \mathrm{~cm}^{-1}, 3292 \mathrm{~cm}^{-1}\right)$. A detailed examination of the relative intensities of peaks related to vibrations of the cellular 10 components (nucleus and cytoplasm) of the C33A, SiHa, HeLa and CaSki infrared spectra revealed the following tendencies:

- Increase in nucleic acid levels with increasing number of HR-HPV copies in the cell or increasing p $16^{\mathrm{INK} 4 \mathrm{~A}}$ expression (figure $5 \mathrm{~A}, 5 \mathrm{D}$ ),

- Decrease in lipid levels with increasing number of HR-HPV copies in the cell or increasing $\mathrm{p} 16^{\mathrm{INK} 4 \mathrm{~A}}$ expression (figure 5B, 5E),
- No tendency for changes in protein levels related to HR-HPV copy number or increasing $\mathrm{p} 16^{\text {INK4A }}$ expression (figure $5 \mathrm{C}, 5 \mathrm{~F}$ ).

As the RMieS-EMSC correction uses the protein based Matrigel as a reference and effectively normalises the protein levels, the third observation is not surprising, and variations in 25 nucleic acids and lipid related features should be considered relative to the protein levels.

The observed increase in nucleic acid levels may be related to an increased number of chromosomes present in HPV infected nuclei. It was reported by Mehés et al. that HPV presence 30 facilitates polyploidisation (increase in chromosome number in a cell nucleus) in cervical squamous cells ${ }^{59}$. Additionally, it is known that binding of HPV DNA to host DNA disrupts 


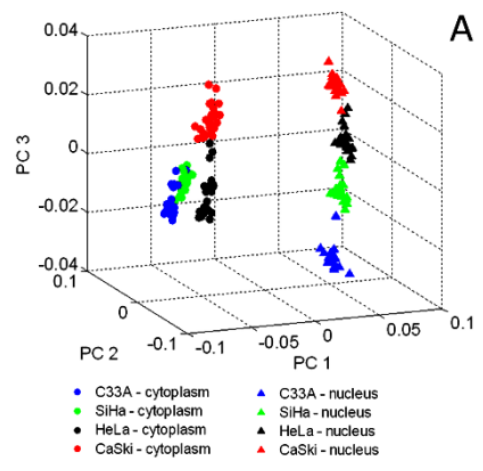

A

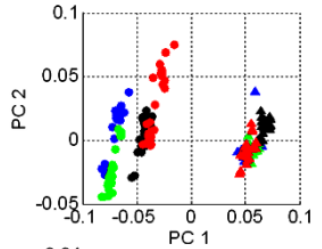

B
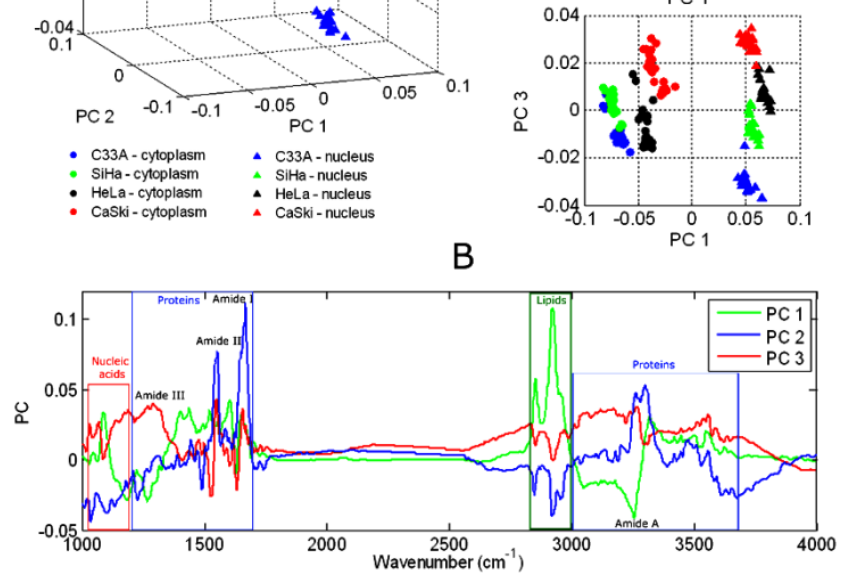

Fig. 6 Principal component analysis results. A - scatterplots presented in three and two dimensional form, B - principal component loadings with marked regions of the main biocomponent contribution.

5 the normal function of the cellular proteins and as a consequence, the host cell accumulates more and more damaged DNA that cannot be repaired ${ }^{60}$.

CaSki cells are known to be the most malignant and in the spectra of the cytoplasm and nucleus representing this cell 10 line the highest level of nucleic acids was observed. A similar increase of the nucleic acid related peaks in cancerous cervical cells was noticed in previous studies 33,42 and is confirmed by these observations. Changes in lipid levels are possibly associated with the disruption of the membrane 15 functionality caused by the virus which influences lipid rafts 61. A similar behaviour was noted and reported in our previous study on cervical cancer cell lines, wherein both Raman and FTIR (point mode) techniques were utilised ${ }^{62}$. Moreover, it was reported previously by Wong et al. that the degree of 20 disorder of methylene chains in membrane lipids increases in cervical neoplastic cells ${ }^{63}$. The absence of any clear relationship between protein levels and HPV copy number is expected, as the presence of HR-HPV in the cell results in functional over- and under- expression of only select 25 biomarker proteins ${ }^{5}$, while the level of the other proteins would not be affected. The variation of the spectroscopic features associated with the nuclear lipids, proteins and nucleic acids as a function of the HPV copy number was found to be sublinear and to be well fitted with a similar 30 function to that employed to describe the variation of the p16 ${ }^{\mathrm{INK} 4 \mathrm{~A}}$ levels with HPV copy number in figure 2. Notably, the dependences of the cytoplasmic lipids, proteins and nucleic acids on the $\mathrm{p} 16^{\text {INK4A }}$ levels, as identified by fluorescence were found to be linear.

35

\section{Principal Component Analysis}

Figure 6 shows the results of Principal Component Analysis
(PCA) of the spectral data for the four cell lines. The analysis clearly differentiates between nuclear and cytoplasmic FTIR 40 signals for each cell line. The percentage variance explained by the first three principal components was $88.34 \%, 4.44 \%$ and $2.23 \%$ for $\mathrm{PC} 1, \mathrm{PC} 2$ and $\mathrm{PC} 3$, respectively. The PCA scatterplot (figure 6A) reveals that the cytoplasm spectra of $\mathrm{C} 33 \mathrm{~A}$ and $\mathrm{SiHa}$ are close to each other, suggesting similarities 45 in cytoplasmic composition of these cell lines. However, in terms of the nuclear data, the cell lines are very well separated. C33A are HPV negative, while SiHa contain a very low number of integrated HPV copies per cell (1-2). HPV DNA and host cell DNA integration occurs within the nucleus 50 of a cell. Thus, the differences between C33A (HPV negative - no integration) and SiHa (HPV positive - integration) at the nuclear level are understandable. It is possible, that in the cytoplasm, biochemical changes in the cell affected by a very low number of HPV copies are not as prominent as in the 55 nucleus. In the case of cells infected by 20-50 HPV copies (HeLa) and 60-600 copies (CaSki), biochemical changes within the cytoplasm become more prominent resulting in, for example, a stronger under- and overexpression of cytoplasmic proteins. Thus the cytoplasmic signals of $\mathrm{C} 33 \mathrm{~A}$ and $\mathrm{SiHa}$ are 60 distributed close to each other, while HeLa and CaSki are very well separated. In general, the clusters representing the spectra of cytoplasm are more dispersed than those corresponding to cell nuclei. This could be explained by the fact that the cytoplasm is much more variable in its 65 composition compared to the nucleus, therefore exhibiting more variation in the FTIR signals. Although, the Resonant Mie scattering correction algorithm cannot be considered perfect as evidenced by the incomplete baseline correction in the loadings plots of the PCs, (figure 6B), it is considered the 70 most effective method currently available allowing for removing the Mie scattering influence from the FTIR signals. The separation between the nuclear and the cytoplasmic clusters is clearly due to the first principal component (PC1). Based on the PC1 loading (figure 6B), it can be concluded 75 that the biochemical variability between these two cellular components primarily arises from the lipid levels (region of $\left.2800-3000 \mathrm{~cm}^{-1}\right)$. In PC1, protein contributions are also notable $\left(1400-1700 \mathrm{~cm}^{-1}, 3000-3500 \mathrm{~cm}^{-1}\right)$. PC1 also shows nucleic acid variations $\left(1050-1200 \mathrm{~cm}^{-1}\right)$, the symmetric 80 phosphodiester group stretching band in RNA (peak at $1120 \mathrm{~cm}^{-1}$ ) being strongly accented in cytoplasm spectra. This observation is consistent with the mean spectra analysis, whereby the peak at $1120 \mathrm{~cm}^{-1}$ was seen to be prominent in the spectra of the cytoplasm of all cell lines and absent in the 85 signals from nuclei (figure 4 - peak III in enlarged nucleic acid region). PC2 indicates a high variability of the proteins (Amide I, Amide II, Amide III, Amide A). This separation of the cell lines confirms the study of Kelly et al., where amide bands were also determined to be a source of differentiation of 90 the cervical cancer cells ${ }^{27}$. In PC2 there is also a lipid contribution present originating from symmetric and asymmetric vibrations of the $\mathrm{CH}_{2}$ and $\mathrm{CH}_{3}$ groups. A two dimensional representation of the scatterplot PC1 vs. PC2 (figure 6A) shows that the internal variability of the ${ }_{95}$ cytoplasm signals is extended along PC2. Therefore, it can be 

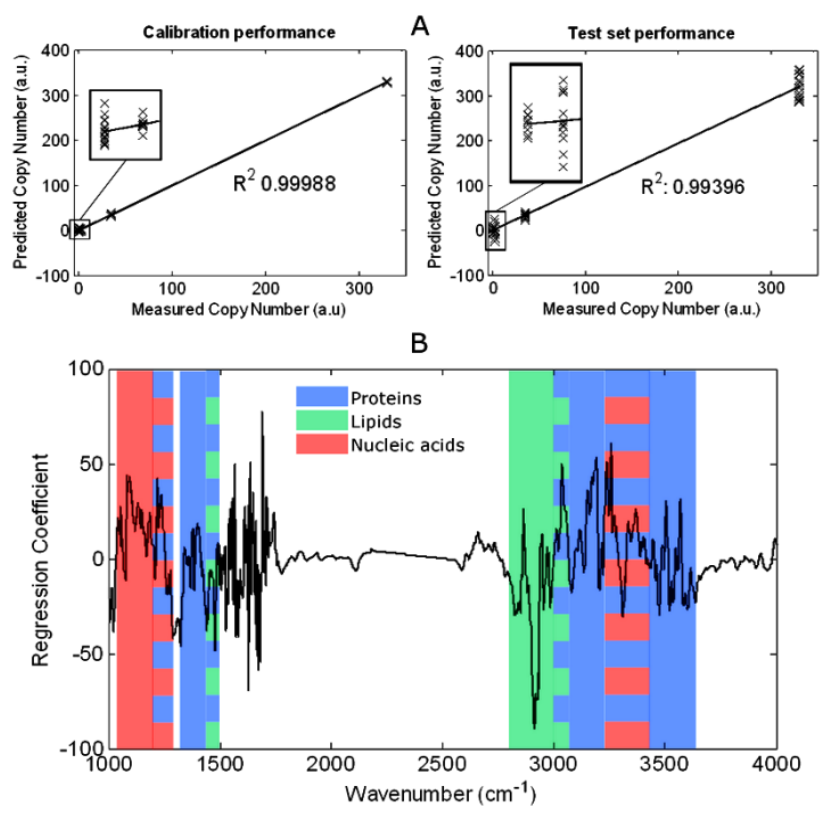

Fig. 7 Partial Least Squares analysis results targeting the $\mathrm{p} 16^{\mathrm{INK} 4 \mathrm{~A}}$ expression level prediction based on the FTIR spectral features.

concluded that it originates mainly from variations in the 5 protein levels within the cell. Groups of points in the PCA scatterplot representing the spectroscopic signatures of $\mathrm{C} 33 \mathrm{~A}$, $\mathrm{SiHa}, \mathrm{HeLa}$ and CaSki cell lines recorded from nuclei are separated along the third principal component. In PC3 contributions of all components are present; nucleic acids, 10 lipids and proteins. This illustrates that the HR-HPV infection influences the entire biochemistry of the cell through a chain of reactions ${ }^{64}$.

\section{Partial Least Squares Analysis}

In order to further elucidate the multivariate spectral 15 signatures which are specifically related to HPV infection, Partial Least Squares (PLS) analysis was performed. Figure 5 demonstrates that $\mathrm{p} 16^{\mathrm{INK} 4 \mathrm{~A}}$ levels as measured by fluorescence intensity are approximately linearly correlated with the univariate spectral features and thus, as PLS is a linear model, 20 these values are employed as targets for the PLS analysis. The model can therefore be applied to the FTIR data to elucidate multivariate signatures which are correlated to $\mathrm{p} 16^{\mathrm{INK} 4 \mathrm{~A}}$ expression level, and therefore, in accordance with figure 2, to HPV infection levels. Once established, these variation ${ }_{25}$ patterns can then be applied to unknown samples to screen for the biomarker levels. As $\mathrm{p} 16^{\mathrm{INK} 4 \mathrm{~A}}$ was found to be predominantly expressed in cytoplasmic regions of the cells, signals recorded from the cytoplasm were utilised in the analysis. Calibration (based on $40 \%$ of the data) and test set 30 performance (based on $60 \%$ of the data) are presented in figure 7A and demonstrate a very good fit to the model. As shown in figure 7B, the PLS loading exhibits variations originating from proteins, primarily as sub-bands of Amide A $\left(3000-3700 \mathrm{~cm}^{-1}\right)$ and Amide III $\left(1230-1250 \mathrm{~cm}^{-1}\right)$, and are 35 associated with the chain of biochemical disruption in protein regulation caused by HPV presence ${ }^{64}$ Another prominent spectral feature differentiating the cell lines, and present in PC loadings and the PLS loading, is the lipid contribution. Again, the presence of HR-HPV is seen to significantly influence the 40 lipid balance within the cell ${ }^{61}$, and thus it can be expected that the vibrations of lipid component groups differentiate cells with various HPV copy number. This differentiation was distinctly manifest in the mean spectra of the cytoplasm and nucleus (figure 4 - enlarged lipid region of $2800-3050 \mathrm{~cm}^{-1}$ ). ${ }_{45}$ Furthermore, the DNA and RNA related peaks are exhibited in the range of $1050-1250 \mathrm{~cm}^{-1}$, (sym. and asym. $\mathrm{PO}_{2}$ str. $\mathrm{CO}$ str.) and $3200-3400 \mathrm{~cm}^{-1}$. Such activity in the region of the nucleic acid features is consistent with the profile of PC1 and PC3 (figure 6B), which differentiates the cell line signals, and 50 as a consequence distinguishes cells as a function of HPV copy number.

\section{Conclusions}

Confocal fluorescence microscopy and flow cytometry revealed that $\mathrm{p} 16^{\mathrm{INK} 4 \mathrm{~A}}$ expression levels were correlated with $55 \mathrm{HPV}$ infection levels in cervical cancer cell lines. This confirms $\mathrm{p} 16^{\mathrm{INK} 4 \mathrm{~A}}$ as a potential diagnostic marker of cervical cancer, supporting the results of many other studies $47-48,65$. Integration of HR-HPV sequences into the cell genome is considered to be an important event in the progression of 60 cervical neoplasia. In this study, a correlation between the integrated HPV copy number and intensity of $\mathrm{p} 16^{\mathrm{INK} 4 \mathrm{~A}}$ was observed. FTIR imaging allowed for identification of the specific spectral features of nuclear and cytoplasmic regions of the cervical cancer cells, indicating the differences between 65 the two, in terms of lipid and RNA levels. PCA analysis revealed that the spectral analysis clearly separates the nuclear and cytoplasmic characteristic signals, and additionally distinguishes the cell lines. At low copy number, HPV predominantly influences the nucleus of the cell, whereas 70 increased copy number impacts on the cytoplasmic signatures. A model of $\mathrm{p} 16^{\mathrm{INK} 4 \mathrm{~A}}$ expression level prediction based on FTIR spectroscopy was constructed utilising PLS analysis. Modelling was predominantly based on spectral features arising from nucleic acid, lipid and protein contributing 75 features, which are influenced by the HPV interaction with the host cell. Notably, this work proves that the wavenumbers above $2700 \mathrm{~cm}^{-1}$ may exhibit crucial information. This region of the FTIR spectrum has been neglected in many studies conducted on biological samples.

80 A potential application of vibrational spectroscopy to cervical cancer screening and diagnosis requires a full understanding of the spectral information and its correlation with existing screening and diagnostic methods such as Pap testing or colposcopy. However, the field of the cervical cancer 85 recognition and detection is still developing with new biomarkers ${ }^{5}$ being identified that may be considered as adjuncts to existing cervical cytology and pathology methods. Biomarkers such as $\mathrm{p} 16^{\mathrm{INK} 4 \mathrm{~A}}$ have been found to be useful for low-grade lesions ${ }^{66-69}$ making them particularly 90 attractive. Thus, a correlation and explanation of the spectral information with these new biomarkers is a new challenge for biospectroscopists working on future cancer diagnostic systems. 


\section{Acknowledgement}

This work was funded by the Department of Education and Science Technological Sector Research Strand III programme and enabled through the National Biophotonics and Imaging 5 Platform, Ireland, and the Integrated NanoScience Platform for Ireland, both funded by the Irish Government's Programme for Research in Third Level Institutions, Cycle 4, National Development Plan 2007-2013.

\section{Notes and references}

${ }_{10}^{a}{ }^{a}$ RESC, Focas Research Institute, Dublin Institute of Technology, Kevin Street, Dublin 8, Ireland. E-mail: kamila.m.ostrowska@gmail.com.

${ }^{b}$ School of Biological Sciences, Dublin Institute of Technology, Kevin Street, Dublin 8, Ireland.

${ }^{c}$ Department of Pathology, Coombe Women \& Infants University 15 Hospital, Dolphin's Barn Street, Dublin 8, Ireland.

${ }^{d}$ Focas Research Institute, Dublin Institute of Technology, Kevin Street, Dublin 8, Ireland.

20 1. D. Parkin, F. Bray, J. Ferlay and P. Pisani, CA Cancer J Clin, 2002, 55, 74-108.

2. D. Parkin and F. Bray, Vaccine, 2006, 24 Suppl 3, S3/11-25.

3. J. Walboomers, M. Jacobs, M. Manos, F. Bosch, J. Kummer, K. Shah, P. Snijders, J. Peto, C. Meijer and N. Muñoz, J Pathol, 1999,

$25 \quad \mathbf{1 8 9}, 12-19$

4. N. Munoz, F. X. Bosch, S. de Sanjose, R. Herrero, X. Castellsague, K. V. Shah, P. J. Snijders and C. J. Meijer, N Engl J Med, 2003, 348, 518-527.

5. C. M. Martin, L. Kehoe, C. O. Spillane and J. J. O'Leary, Mol 30 Diagn Ther, 2007, 11, 277-290.

6. A. Kalof, M. Evans, L. Simmons-Arnold, B. Beatty and K. Cooper, Am J Surg Pathol, 2005, 29, 674-679.

7. M. Dray, P. Russell, C. Dalrymple, N. Wallman, G. Angus, A. Leong, J. Carter and B. Cheerala, Pathology, 2005, 37, 112-124.

358 T. Yu, M. J. Ferber, T. H. Cheung, T. K. Chung, Y. F. Wong and D. I. Smith, Cancer Genet Cytogenet, 2005, 158, 27-34.

9. N. Ozgul, A. Cil, G. Bozdayi, A. Usubutun, D. Bulbul, S. Rota, M. Kose, A. Biri and A. Haberal, J Obstet Gynaecol Res, 2008, 34, 865-871.

$4010 . \quad$ N. Murphy, M. Ring, C. Heffron, B. King, A. Killalea, C. Hughes, C. Martin, E. McGuinness, O. Sheils and J. O'Leary, J Clin Pathol, 2005, 58, 525-534.

11. N. Missaoui, S. Hmissa, L. Frappart, A. Trabelsi, A. Ben Abdelkader, C. Traore, M. Mokni, M. T. Yaacoubi and S. Korbi,

45 Virchows Arch, 2006, 448, 597-603.

12. N. Murphy, M. Ring, A. G. Killalea, V. Uhlmann, M. O'Donovan, F. Mulcahy, M. Turner, E. McGuinness, M. Griffin, C. Martin, O. Sheils and J. J. O'Leary, J Clin Pathol, 2003, 56, 56-63.

13. S. Candefjord, K. Ramser and O. A. Lindahl, J Med Eng Technol, 2009, 33, 585-603.

14. C. Kendall, M. Isabelle, F. Bazant-Hegemark, J. Hutchings, L. Orr, J. Babrah, R. Baker and N. Stone, Analyst, 2009, 134, 1029-1045.

15. C. Krafft, G. Steiner, C. Beleites and R. Salzer, J Biophotonics, 2009, 2, 13-28.

55 16. F. Bazant-Hegemark, K. Edey, G. R. Swingler, M. D. Read and N. Stone, Technol Cancer Res Treat, 2008, 7, 483-496.
17. M. J. Walsh, M. J. German, M. Singh, H. M. Pollock, A. Hammiche, M. Kyrgiou, H. F. Stringfellow, E. Paraskevaidis, P. L. Martin-Hirsch and F. L. Martin, Cancer Lett, 2007, 246, 1-11.

60 18. N. S. Eikje, K. Aizawa and Y. Ozaki, Biotechnol Annu Rev, 2005, 11, 191-225.

19. R. J. Meier, Chem Soc Rev, 2005, 34, 743-752.

20. M. Diem, J. M. Chalmers and P. R. Griffiths, Vibrational spectroscopy for medical diagnosis, John Wiley \& Sons,

65 Chichester, England; Hoboken, NJ, 2008.

21. J. I. Chang, Y. B. Huang, P. C. Wu, C. C. Chen, S. C. Huang and Y. H. Tsai, Gynecol Oncol, 2003, 91, 577-583.

22. L. Chiriboga, P. Xie, H. Yee, D. Zarou, D. Zakim and M. Diem, Cell Mol Biol (Noisy-le-grand), 1998, 44, 219-229.

7023 . L. Chiriboga, H. Yee, M. Diem and B. Wood, Gynecol Oncol, 2003, 91, 275-276; author reply 276-277.

24. M. A. Cohenford, T. A. Godwin, F. Cahn, P. Bhandare, T. A. Caputo and B. Rigas, Gynecol Oncol, 1997, 66, 59-65.

25. S. G. El-Tawil, R. Adnan, Z. N. Muhamed and N. H. Othman, 75 Pathology, 2008, 40, 600-603.

26. M. Fung Kee Fung, M. Senterman, P. Eid, W. Faught, N. Z. Mikhael and P. T. Wong, Gynecol Oncol, 1997, 66, 10-15.

27. J. G. Kelly, K. T. Cheung, C. Martin, J. J. O'Leary, W. Prendiville, P. L. Martin-Hirsch and F. L. Martin, Clin Chim Acta, 2010, 411, 1027-1033.

28. C. M. Krishna, G. D. Sockalingum, B. M. Vadhiraja, K. Maheedhar, A. C. Rao, L. Rao, L. Venteo, M. Pluot, D. J. Fernandes, M. S. Vidyasagar, V. B. Kartha and M. Manfait, Biopolymers, 2007, 85, 214-221.

85 29. S. R. Lowry, Cell Mol Biol (Noisy-le-grand), 1998, 44, 169-177.

30. S. Mark, R. K. Sahu, K. Kantarovich, A. Podshyvalov, H. Guterman, J. Goldstein, R. Jagannathan, S. Argov and S. Mordechai, J Biomed Opt, 2004, 9, 558-567.

31. S. Mordechai, R. K. Sahu, Z. Hammody, S. Mark, K. Kantarovich, 90 H. Guterman, A. Podshyvalov, J. Goldstein and S. Argov, J Microsc, 2004, 215, 86-91.

32. B. J. Morris, C. Lee, B. N. Nightingale, E. Molodysky, L. J. Morris, R. Appio, S. Sternhell, M. Cardona, D. Mackerras and L. M. Irwig, Gynecol Oncol, 1995, 56, 245-249.

95 33. S. Neviliappan, L. Fang Kan, T. Tiang Lee Walter, S. Arulkumaran and P. T. Wong, Gynecol Oncol, 2002, 85, 170-174.

34. C. H. Petter, N. Heigl, M. Rainer, R. Bakry, J. Pallua, G. K. Bonn and C. W. Huck, Curr Med Chem, 2009, 16, 318-326.

35. A. Podshyvalov, R. K. Sahu, S. Mark, K. Kantarovich, H. 100 Guterman, J. Goldstein, R. Jagannathan, S. Argov and S. Mordechai, Appl Opt, 2005, 44, 3725-3734.

36. B. Rigas, K. LaGuardia, L. Qiao, P. S. Bhandare, T. Caputo and M. A. Cohenford, J Lab Clin Med, 2000, 135, 26-31.

37. R. Sindhuphak, S. Issaravanich, V. Udomprasertgul, P. Srisookho, 105 S. Warakamin, S. Sindhuphak, R. Boonbundarlchai and N. Dusitsin, Gynecol Oncol, 2003, 90, 10-14.

38. W. Steller, J. Einenkel, L. C. Horn, U. D. Braumann, H. Binder, R. Salzer and C. Krafft, Anal Bioanal Chem, 2006, 384, 145-154.

39. M. J. Walsh, M. N. Singh, H. M. Pollock, L. J. Cooper, M. J. German, H. F. Stringfellow, N. J. Fullwood, E. Paraskevaidis, P. L. Martin-Hirsch and F. L. Martin, Biochem Biophys Res Commun, 2007, 352, 213-219.

40. B. R. Wood, L. Chiriboga, H. Yee, M. A. Quinn, D. McNaughton and M. Diem, Gynecol Oncol, 2004, 93, 59-68. 
41. B. R. Wood, M. A. Quinn, B. Tait, M. Ashdown, T. Hislop, M. Romeo and D. McNaughton, Biospectroscopy, 1998, 4, 75-91.

42. H. M. Yazdi, M. A. Bertrand and P. T. Wong, Acta Cytol, 1996, 40, 664-668.

5 43. J. M. Schubert, B. Bird, K. Papamarkakis, M. Miljkovic, K. Bedrossian, N. Laver and M. Diem, Lab Invest, 2010, 90, 10681077.

44. K. M. Ostrowska, A. Malkin, A. Meade, J. O'Leary, C. Martin, C. Spillane, H. J. Byrne and F. M. Lyng, Analyst, 2010, 135, 30873093.

45. A. D. Meade, C. Clarke, F. Draux, G. D. Sockalingum, M. Manfait, F. M. Lyng and H. J. Byrne, Anal Bioanal Chem, 2010.

46. P. Bassan, A. Kohler, H. Martens, J. Lee, H. J. Byrne, P. Dumas, E. Gazi, M. Brown, N. Clarke and P. Gardner, Analyst, 2010, 135,

15

47. T. Sano, T. Oyama, K. Kashiwabara, T. Fukuda and T. Nakajima, Pathol Int, 1998, 48, 580-585.

48. R. Klaes, T. Friedrich, D. Spitkovsky, R. Ridder, W. Rudy, U. Petry, G. Dallenbach-Hellweg, D. Schmidt and M. von Knebel Doeberitz, Int J Cancer, 2001, 92, 276-284.

49. N. Murphy, M. Ring, A. Killalea, V. Uhlmann, M. O'Donovan, F. Mulcahy, M. Turner, E. McGuinness, M. Griffin, C. Martin, O. Sheils and J. O'Leary, J Clin Pathol, 2003, 56, 56-63.

50. K. Milde-Langosch, S. Riethdorf, A. Kraus-Poppinghaus, L. 25

51. S. N. Agoff, P. Lin, J. Morihara, C. Mao, N. B. Kiviat and L. A. Koutsky, Mod Pathol, 2003, 16, 665-673.

52. N. Murphy, C. C. Heffron, B. King, U. G. Ganuguapati, M. Ring, E. McGuinness, O. Sheils and J. J. O'Leary, Virchows Arch, 2004, 445, 610-615.

53. N. Murphy, M. Ring, C. C. Heffron, B. King, A. G. Killalea, C. Hughes, C. M. Martin, E. McGuinness, O. Sheils and J. J. O'Leary, J Clin Pathol, 2005, 58, 525-534.

54. S. S. Wang, M. Trunk, M. Schiffman, R. Herrero, M. E. Sherman, Rodriguez, S. Chen, A. Reichert, C. von Knebel Doeberitz, R. Ridder and M. von Knebel Doeberitz, Cancer Epidemiol Biomarkers Prev, 2004, 13, 1355-1360.

55. Z. Movasaghi, S. Rehman and I. U. Rehman, Appl. Spectrosc. Rev., $40 \quad 2007,42,493-541$.

56. J. W. Black and P. Leff, Proc R Soc Lond B Biol Sci, 1983, 220, 141-162.

57. G. Lizard, M. C. Chignol, Y. Chardonnet, C. Souchier, M. Bordes, D. Schmitt and J. P. Revillard, J Immunol Methods, 1993, 157, 31-

$45 \quad 38$

58. K. Adler, T. Erickson and M. Bobrow, Histochem Cell Biol, 1997, 108, 321-324.

59. G. Mehés, N. Speich, M. Bollmann and R. Bollmann, Pathol Oncol Res, 2004, 10, 142-148.

50 60. E. M. Burd, Clin Microbiol Rev, 2003, 16, 1-17.

61. F. A. Suprynowicz, G. L. Disbrow, E. Krawczyk, V. Simic, K. Lantzky and R. Schlegel, Oncogene, 2008, 27, 1071-1078.

62. K. M. Ostrowska, A. Malkin, A. D. Meade, J. J. O'Leary, C. Martin, C. O. Spillane, H. J. Byrne and F. M. Lyng, Analyst, 2010.

5563. P. T. Wong, R. K. Wong, T. A. Caputo, T. A. Godwin and B. Rigas, Proc Natl Acad Sci U S A, 1991, 88, 10988-10992.

64. J. Doorbar, Clin Sci (Lond), 2006, 110, 525-541.

65. N. Murphy, C. C. Heffron, B. King, U. G. Ganuguapati, M. Ring, E. McGuinness, O. Sheils and J. J. O'Leary, Virchows Arch., 2004, 445, 610-615. Epub 2004 Sep 2018.

66. M. Benevolo, M. Mottolese, F. Marandino, G. Vocaturo, R. Sindico, G. Piperno, L. Mariani, I. Sperduti, P. Canalini, R. P. Donnorso and A. Vocaturo, Mod Pathol, 2006, 19, 384-391.

67. B. Passamonti, D. Gustinucci, P. Recchia, S. Bulletti, A. Carlani, 65 E. Cesarini, M. R. D'Amico, V. D'Angelo, E. Di Dato, N. Martinelli, M. Malaspina and N. Spita, Pathologica, 2010, 102, 611.

68. G. Negri, G. Bellisano, G. F. Zannoni, F. Rivasi, A. Kasal, F. Vittadello, S. Antoniazzi, G. Faa, R. Ambu and E. Egarter-Vigl, Am J Surg Pathol, 2008, 32, 1715-1720.

69. G. R. Focchi, I. D. Silva, N. C. Nogueira-de-Souza, C. Dobo, C. T. Oshima and J. N. Stavale, J Low Genit Tract Dis, 2007, 11, 98104. 